\title{
Challenges, Cooperation and Paradoxes in the Coca Cocaine Complex
}

MARIÁ DE LOS ÁNGELES LASA ${ }^{1}$, University of Camerino Italy

\begin{abstract}
7 be coca-cocaine complex in South America is one of the most serious threats to the region's political, economic and social institutions. It has infected the public and private sectors with the virus of corruption and violence, and it has brought about the intervention of extra-regional actors that have
\end{abstract} contributed to worsening the situation. In the fight against this threat since the 1970s, South American countries have had the support of the United States (US) and the European Union (EU) which, these being the world's largest consumers of cocaine in the world, has become the source of a vicious paradox: the challenges for South American states arise not only from the coca-cocaine complex itself, but also from the cooperation of those world superpowers in the fight against it. This paper analyses both the cooperation among drug actors - an issue that has bistorically been overlooked-, and the previously mentioned paradox in the case of South American states and the EU.

\footnotetext{
${ }^{1}$ Mariá de Los Ángeles Lasa, born in Argentina 1986 is a CUIA Scholar and Doctoral Fellow in Social Sciences on Work and Legality at the Department of Law and Politics, School of Advanced Studies, Università degli Studi di Camerino (Italy). She is currently Visiting Researcher at the Lozano Long Institute of Latin American Studies (College of Liberal Arts, University of Texas at Austin). She has published several articles on public corruption, drugs and organized crime in books and academic journals in Argentina, Italy, Mexico and Switzerland. Her interests include security studies, drug trafficking, counternarcotics policies, and violence and criminality in Latin America. She would like to thank her Ph.D. Advisor, Dr. Giovanna Ricci, for providing useful comments on her first drafts, Prof. Andrea Vartalitis, from the National University of Villa María (Argentina), for her advice and careful editing of the final English version of this paper.
} 


\section{Introduction}

$\mathrm{C}$ oca leaves have been chewed by Andean people for centuries "to help combat hunger and to overcome fatigue and exhaustion caused by the high altitude, as well as for traditional and religious practices" (Dreyfus, 2001, 22). Since Pre-Columbian times the coca bush is deeply rooted in the Andean culture, but its rich cultural dimension has no bearing on the harmful effects it has had on the rest of the world once it is transformed into cocaine.

The coca plant is a medium-sized bush that grows in tropical climate regions, "anywhere between 100 and 1.700 meters above sea level" (Mejía and Posada, 2010, 255). There are more than 250 varieties of coca bushes that can be harvested from three to six times per year for a period of 10 to 25 years depending on the level of care it receives.

Depending on the coca variety, the geographical region and the number of bushes cultivated per hectare,

1 hectare planted with coca bushes produces, on average, between 1,000 and 1,200 kilograms of fresh coca leaf per harvest. Between 1.1 and 1.4 kilograms of cocaine can be produced from 1 kilogram of coca leaf. Using an average of four harvests per year (...), we arrive at a general production estimate of between 5 and 6 kilograms of cocaine per hectare per year." (Mejía and Posada, 2010, 255).

According to the 2012 World Drug Report, the total number of hectares illegally cultivated with coca bush in 2010 was estimated in 149.200 (UNODC, 2012, 35).

Produced with crystalline tropane alkaloid, a chemical obtained from the leaves of the coca bush, cocaine hydrochloride is a highly addictive illegal drug. "It is either snorted or dissolved in water and injected," (Mejía and Posada, 2010, 255) and its consumption triggers different physical effects.

In moderate doses, it causes disturbance in heart rates, elevated blood pressure, dilated pupils, decreased appetite, irritability, and argumentative behavior, among other effects. In large doses it can lead to loss of coordination, collapse, blurred vision, dizziness, anxiety, heart attacks, chest pain, respiratory failure, strokes, seizures, headaches, abdominal pain, nausea, and paranoia (Mejía and Posada, 2010, 256).

Cocaine is the second most consumed illegal drug in the US (after marihuana) and the third in most European countries after marihuana and heroin (Mejía and Posada, 2010, 256). From the perspective of the demand of drugs, in fact, the US is to have the largest number of cocaine users worldwide with more than 5 million users aged between 15 to 64; followed by Western European countries with an estimated number of 4 million users within the same age range (UNODC, 2011, 86).

\section{The coca-cocaine complex: a real threat to South American countries}

Specialized literature in the field of International Security Studies defines drug trafficking as both an emerging post-Cold War global problem and a national security problem (Cf. Belikow, 2003; Dreyfus, 2001). Regarding South American countries, while the first statement may be debatable for illicit cocaine production, traffic and consumption has clearly been a threat to this region long before the collapse of the bipolar world, the coca-cocaine complex is definitely a national security problem in South America. ${ }^{2}$

\footnotetext{
${ }^{2}$ Traditionally, South America has been divided into two major areas: the Andean Area and the Southern Cone. The Andean Region is composed of five countries: Venezuela, Colombia, Ecuador, Peru and Bolivia. The southernmost area of the Americas includes Argentina, Uruguay and Chile in its most narrow concept, but sometimes Paraguay and the south of Brazil are also included. They all share a common set of historical and political characteristics. Guyana, Suriname and French Guyana are not included as part of the region "because these countries and overseas dominions (in the case of French Guyana) are generally considered part of the Caribbean from both a classical geopolitical point of view and from their role in drug trafficking" (Dreyfus, 2001, 66). Cf. Figure 1.
} 
According to Barry Buzan, national security refers to the situation of freedom from harmful threats to a given state. ${ }^{3}$ This includes freedom from military attack or coercion, from internal subversion, and freedom from the erosion of the political, economic and social values, which are essential to the quality of life and human development. As it can be seen, this concept goes beyond the Weberian concept of State, "defined in politico-institutional terms as a central government" (Dreyfus, 2001, 35). Instead of considering the state and society as two separate phenomena, the state is defined here as a complex socio-political sovereign entity that includes territory, governing institutions and population. But more interestingly in Buzan's approach, is that the concept of threat plays a major role. Threat is defined in his work as a danger to the attributes of the state. These threats can be specific, in the sense that they may have a clear focus and source (posed by a particular state or by a non-state actor); or they can be diffuse threats arising from processes, rather than from a particular actor, object, or policy.

Iveland Lloyd Griffith, taking Buzan's concept of threat, considers what he has called "the drug problem" (Griffith, 1997, 5) to be the major threat to Caribbean states. This problem, the theorist asserts, is a multidimensional dilemma with four areas: production, consumption, trafficking and money laundering (Cf. Griffith, 1997, 1322). On the other hand, Pablo Dreyfus, who has also taken Buzan's concept, has largely studied the spillover negative effects of cocaine producer countries on their

\footnotetext{
3 This state-centric definition belongs to Buzan's classical study People, States \& Fear ([1988] 2009). In his most recent works, Buzan adopts a strong constructivist perspective, so "security issues are made security issues by acts of securitization", a discourse that takes the form of presenting something as an existential threat to a referent object and the audience accepts it as such (Buzan, Wæver, and De Wilde, 1998, 21-22). With this new approach, Buzan abandons the idea that "security is about what is a threat, and the analyst can tell whether something really is a security problem and for whom" (Buzan, Wæver, and De Wilde, 1998, 204).
}

neighbors, and considers that the major threat is drug trafficking and its interaction with the weak nature of South American countries (Dreyfus, 2001, 65). As can be seen, in Dreyfus' work, production and consumption are collateral dimensions of drug trafficking and not problems as such, which means that many actors involved are not taken into account. On the other hand, while Griffith includes money laundering in this equation, I think money laundering -as well as arms trafficking, human trafficking, forced labor, etc.- is itself a related criminal activity and should not be considered part of the coca-cocaine complex.

In my view, the real threat to South American countries is the coca-cocaine complex with its three structural dimensions: production, trafficking and consumption. First of all, I consider these dimensions to be structural because should any of them be absent, we would not have the coca-cocaine complex. Second, although other drugs are also being cultivated in different and important regions in South America, such as opium, marijuana and heroin in Colombia, Guatemala, Mexico, Peru and Venezuela, (UNODC, 2011, 59) and cannabis in Bolivia and Paraguay, I argue that the major threat to South American countries is the cocacocaine complex, mainly for the reasons I summarize as follows:

1. $100 \%$ of the coca and cocaine produced at an international level originates in South America (UNODC, 2011, 59).

2. Poppies in Colombia, for example, started to be sowed by the same organizations devoted to the cultivation, manufacturing, distribution and sale of cocaine. In other words, the complex that gave origin to them is not the opium-heroine but the coca-cocaine complex.

3. Marijuana is widely available to the direct consumer, and it is evident that the illegal organizations related to its commercialization have not been as destabilizing as those connected to the coca-cocaine complex. 
4. Neither the cultivation of cannabis nor the cultivation of poppies has suffered -like has been the case of the cultivation of coca- the intervention in South America of extra-regional actors such as the US and, to a lesser extent, the EU.

Having made that clear, and considering, first, that the coca-cocaine complex is a diffuse threat to the national security in South American countries since it is not posed by a particular actor; and, second, that the three dimensions of the coca-cocaine complex only affect South American countries, the present paper argues that: a) the coca-cocaine complex involves the interaction of regional and extra-regional actors; b) the coca-cocaine complex involves the interaction of states, trans-states, interstates, non-states and individuals actors; and c) the actors involved in the coca-cocaine complex have broadly two kinds of interactions: conflict and cooperation.

\section{Regional and extra-regional actors involved}

Identifying actors in any process is a crucial task if we are to refer to some kind of interaction among them. Since this paper is aimed at analyzing the cooperative interactions between some actors involved in the coca-cocaine complex, we should first identify them.

Without being exhaustive, for the list is always open as the problem continues, the variety of actors involved in the cocacocaine complex include the interaction between regional and extra-regional actors, and among regional actors themselves and extra-regional actors themselves (see Figure 2). On this regard, some explanatory comments are due.

1. The interaction between actors can be either conflictive or cooperative, and all possible levels of conflict or cooperation in that continuum.

2. The term regional actors should be understood as South American actors, and extra-regional actors, are actors from the rest of the world outside South America.

3. Inside each diagram, state actors and state-structure actors (states, armed and police forces); trans-state actors (IGOs); inter-state actors (MNCs and other corporations); non-state actors (criminal groups, paramilitary groups, guerrillas, narcos, drug cartels, NGOs); and individual actors (peasants and individuals) have been included.

In the following section I analyze international cooperative interactions both between non-state actors, such as narco groups, as well as between state and transstate actors, such is the case between South American countries and the EU.

\section{Narco Cooperation vs. International Cooperation}

\section{A definition of cooperation}

In broad terms, international cooperation involves the interaction of individuals, institutions, states and international organizations in the pursuit of a common goal of interests. On a general level, then, the term cooperation can be defined as "any act of working together to one end" (Siitonen, 1990, 11). Going deeper in the analysis, however, one may observe that the very concept of international cooperation is relatively vague.

In his article (1990), Siitonen suggests that the first task to define international cooperation is to identify the international actors in question, and to determine their cooperation criteria. After numerous considerations about the differences between cooperation and other goal oriented actions (such as competition, assistance or rivalry), his conclusion is that international cooperation could be defined as "any form of social interaction between actors allowing them to achieve voluntarily set common goals by sharing certain resources together" (Siitonen, 1990, 13). And the author adds: "cooperation should not be seen as a harmonious relationship where no conflicts exist. On the contrary, cooperation may 
involve hidden power struggles between the partners, and it may as well be a mode of dominance of one partner over another" (Siitonen, 1990, 13).

Bearing in mind that there seems to be a particular tendency in cooperation studies to ignore the problems that arise from international cooperation, the definition provided by Siitonen is optimal in two senses. The first one is that it considers the potential power struggles between cooperative partners. And the second one is that it states that cooperation "is a social interaction between actors" (Siitonen, 1990, 13). Referring to actors alone, from my point of view, Siitonen includes in his definition not only states and international organizations, but non-sovereign actors too. This is a crucial aspect in the scope of this paper, considering that, in the following section, I argue that the challenges for South American states arise not only from the cooperation and conflict between non-state actors, but also from efforts at legal international cooperation.

\section{Narco-cooperation}

Despite the fact that financial interests often lead to conflictive relations among them, cartels and narco-actors often engage in cooperation. This seems to be a forgotten dimension in cooperation studies, which is strange considering the ample evidence that demonstrates the existence of cooperation between South American narco-actors themselves, and South American narcoactors and criminal organizations based in Asia, Europe and Africa.

The cooperation between narco-actors usually involves "market rationalization, trafficking logistics, money laundering, and drug-weapon, drug-cash, and drugs-drugs exchanges" (Griffith, 1997, 18). As a result, as Rensselaer Lee has noted,

International narco-cooperation opens new markets for narcotics and other illegal products, exploits economies of scale for selling in those markets, enhances organized crime's penetration of legal economic and financial systems, and generally increases the power of criminal formations relative to national governments (Lee, 1995, 210).

On the road from the South American Andes to the main consumption markets, hundreds of narco-actors intervene in the process. As a result of this chain of illegal cooperation, in 2010 between 788 and 1,060 tons of cocaine were produced and trafficked (UNODC, 2011, 36).

The first step in the line of production of cocaine is the cultivation of the coca leaf. Just in Colombia, the leading region with the largest extension of cultivated areas, during the 2001-2010 decade an estimated 60.000 to 100.000 families were involved in this illicit agricultural activity (EMCDDA and Europol, 2012, 15). "Many of them grow coca for a living because the frontier areas lack the infrastructure -especially transportation- needed for other, licit crops to be profitable, or because they do not have access to the resources needed to launch sustainable licit agricultural activities" (EMCDDA and Europol, 2012, 15).

After this first stage in which the coca leaf is cultivated, the dynamics of production and trafficking already follow an organized process (Table 1). First, the same farmers who cultivate the coca leaf produce the coca paste, which is nothing else but the coca leaf with lime, ashes, cement or any similar alkaline. Immediately after that, the farmers sell the paste, which is going to be mixed with kerosene, fuel or any other equivalent solvent in order to obtain the cocaine paste to be sold to the local dealers. Since the cocaine paste is usually produced in precarious kitchen laboratories, it is often sold to criminal organizations that have better equipped facilities and the technical resources needed to turn the paste into hydrochloride of cocaine. Currently, these organizations operate in countries like Argentina, Brazil and Venezuela, which have more specialized human resources and easier access to chemicals such as potassium permanganate or ephedrine (Dreyfus, 2001, 305-306). Once the process of production is finished, the transportation of the final product is coordinated for its distribution to 
the main consumption centers: the US and Western European countries.

The moment of trafficking in the cocacocaine complex is probably the most logistically organized among narco-actors. The illegal load not only needs to pass border controls, but it also needs to travel long distances through different geographical areas. For instance, in order to have some cocaine loads delivered to South America and Europe, the cocaine must go across the Atlantic Ocean by boat or by plane, the distance to go being more than 10.000 kilometers.

According to Europol, three main narcomaritime routes towards Europe have been identified: the northern route, which originates in the Caribbean and whose final destination is Portugal or Spain; the centre route, from South America to Europe going through the Canary Islands; and the southern route, from the South coming from Western Africa, and from there to Portugal and Spain. Along these paths, the local narco-actors not only participate in the trafficking but also in the selling in target markets (EMCDDA and Europol, 2012, 15). Some of them, according to available evidence, are "syndicates, Nigerian networks, and Sicilian and Russian organizations" (Griffith, 1997, 18). According to Europol, in the trafficking and selling chain in target markets, "criminal groups located in and around the Netherlands and Belgium, some of them of Colombian origin" (EMCDDA and Europol, 2012, 29) also operate. In the case of the US, the cocaine that arrives there has been handled by Central American gangs and some of the nine drug cartels that currently control Mexico (Federico, 2011, 67-82).

\section{International cooperation: the case of South American states and the European Union}

International cooperation offers the best prospect for dealing with the coca-cocaine complex, especially since all state and nonstate actors "face resource limitations" (Griffith, 1997, 19). However, collaboration among states can also result in conflict. As
Griffith has pointed out, there are two main reasons for this. The first reason is related to domestic factors, "including party rivalry, leadership chances, composition and control of the military, budgetary and economic conditions" (Griffith, 1997, 19). The second reason is to do with "differences among ruling elites, which cause disparate definitions of the nature and severity of threats and, therefore, varies policies and measures to deal with them" (Griffith, 1997, 19).

The War on Drugs led by the US, could be considered as the paradigmatic case of collaboration that results in conflict. After all, the hard core of that counternarcotics policy is a militarized solution to a nonmilitary problem. But the case of study considered here is that of the EU and some South American states.

In the mid 1990s, the Andean Community of Nations (CAN) and the EU started negotiations to fight against drugs jointly; and so did the Rio Group and the EU. Since then, there have been important advances in coordination and cooperation in the fight against drug trafficking. A very important advancement has been the adoption of a Comprehensive Action Plan on Drugs (Panama, 1999) and the different declarations of intention like the one signed in Quito in 2009 of Coordination and Cooperation Mechanism on Drugs among Latin America, the Caribbean and the European Union. Furthermore, in 2009, the Cooperation in Anti-drugs Policies between Latin America and the European Union (COPOLAD) started with the financial support of the European Commission of 6 million Euros. Besides, there exist programs which finance the alternative development of coca leaf cultivation. By the end of 2009, the funds assigned to these projects were approximately 360 million Euros (EMCDDA and Europol, 2012, 34).

In spite of the progress of these cooperative efforts through their institutionalization, the goals of the abovementioned agreements reflect the priorities of the anti-narcotics policy of the EU: reducing the demand and 
supply of cocaine ${ }^{4}$. It is highly positive that these programs have not been militarized, like in the case of the cooperation given by the US. In this sense, as has been noted by the International Crisis Group,

In Europe, US and US-led counter-drug policies in Latin America are often perceived as efforts to exert influence on domestic politics in Latin America and as counterproductive attempts to reduce the scale of the drug problem by concentrating on fighting supply in the source and transit countries. (...) The EU does, however, prioritize reducing supply through interdiction and law enforcement, in particular at its borders and within the Union, and curbing demand at home through prevention, treatment and rehabilitation programs (International Crisis Group, 2008, 9).

Nevertheless, it is evident that there exists an important gap between Europe and South America in terms of diagnosing the problem; a gap that turns anti-drug policies ineffective and inefficient to fight against the cocacocaine complex, and therefore result beneficial to narco-actors.

The realities of drug production and trafficking in Latin America and limited demand reduction progress in Europe, (...) show that EU policy is falling short of its goals. The emphasis on supply reduction through law enforcement and interdiction within the $\mathrm{EU}$ and its immediate neighborhood has not significantly interrupted the cocaine flow. A European Commission official acknowledged that once routes and methods have been detected and action

\footnotetext{
${ }^{4}$ The basic premises of EU policy are contained in the EU Drugs Strategy (2005-2012) and the EU Action Plan on Drugs (2005-2008), which seek to coordinate the actions of the 27 Member States and facilitate international dialogue. Cf. European Council, "EU drugs strategy for the period 2005-2012." Accessed September 23, 2012. Available at http://www.emcdda.europa.eu/html.cfm/index1016 11EN.html "EU Action Plan on Drugs 2005-2008." Accessed November 14, 2012. Available at http://www.emcdda.europa.eu/html.cfm/index1036 0EN.html
}

taken, the traffickers adjust and find new ways to supply the European market: 'The traffickers are more intelligent than we are, and they change routes quickly' (International Crisis Group, 2008, 9).

While South America receives financial support to work on the reduction of the drug demand and supply, the real problems to be faced are infinitely worse: criminal groups, victims of violence, impoverished farmers, weakened governments, corrupted police officers, destroyed ecosystems and consumers of discarded garbage of cocaine. Genuine cooperation should respond to the needs in each region, and not only taking into account the needs of European countries. Disregarding this urgency in Latin America is actually undoing all the efforts made to fight against the coca-cocaine complex.

\section{Concluding remarks}

The negative effects of the intended cooperation from the two most important extra-regional actors in the fight against drugs in South America, i.e. the US and Europe, are quite evident. The militarized cooperation of the US in the region has provoked a rise in the violation of human rights; more corruption of the military and police forces; the weakening of democracy in the Andean countries; and the recrudescence of political violence ${ }^{5}$, among others. On the other hand, the unidirectional cooperation of the EU has concentrated on responding to the flux of drug supply and demand which affects Europe, neglecting the real and serious problems that South America has to face.

In the meantime, narco-actors are advancing in their foul pursuits and, although it would be too risky to affirm that narco-cooperation has

\footnotetext{
5 On the negative effects of the $W$ ar on Drugs led by the US, it is highly recommended to consult the numerous studies financed by the Washington Office on Latin America (WOLA). Among them, those directed by Coletta A. Youngers and Eileen Rosin deserve special attention (Youngers and Rosin, 2005).
} 
been more effective than international cooperation among legal actors, there is not enough evidence to assert that it has not. This brings me back to the paradox that inspired this paper: the challenges for South American states arise not only from the coca-cocaine complex itself, but also from the efforts made to fight against it. Nevertheless, and while the history of the coca-cocaine complex in South America is the history of paradoxes and misconceptions of what the real nature of this scourge is and where the real problems lie, history can be changed... but understanding comes first. 
Tables and figures

Table 1: Stages in the process of elaboration of cocaine and its by-products

\begin{tabular}{|c|c|c|c|c|}
\hline Coca leaf & + & Alkaline (lime, cement, etc.) & $=$ & Coca Paste \\
\hline Coca Paste & + & Kerosene and sulphuricacid & $=$ & Cocaine base paste \\
\hline \multirow{2}{*}{$\begin{array}{c}\text { Cocaine base } \\
\text { paste }\end{array}$} & \multirow[b]{2}{*}{+} & $\begin{array}{l}\text { Sodium bicarbonate and acid, } \\
\text { acetone, ether, etc. }\end{array}$ & \multirow{2}{*}{$=$} & Crack \\
\hline & & $\begin{array}{l}\text { Potassium permanganate, } \\
\text { sulphuric acid and ammonia }\end{array}$ & & $\begin{array}{c}\text { Cocaine washed or cocaine } \\
\text { base }\end{array}$ \\
\hline Cocaine base & + & $\begin{array}{l}\text { Acetone, hydrocloridic acid and } \\
\text { potassium permanganate }\end{array}$ & $=$ & Hydrochloride of cocaine \\
\hline $\begin{array}{l}\text { Hydrochloride } \\
\text { of cocaine }\end{array}$ & + & $\begin{array}{l}\text { Sodium bicarbonate and acid, } \\
\text { acetone, ether, etc. }\end{array}$ & $=$ & Crack (of highest quality) \\
\hline
\end{tabular}

Source: Carrió, Cinquierrui, and Martello, 2006, 7.

Figure 1: The Andean Region and the Southern Cone in South America

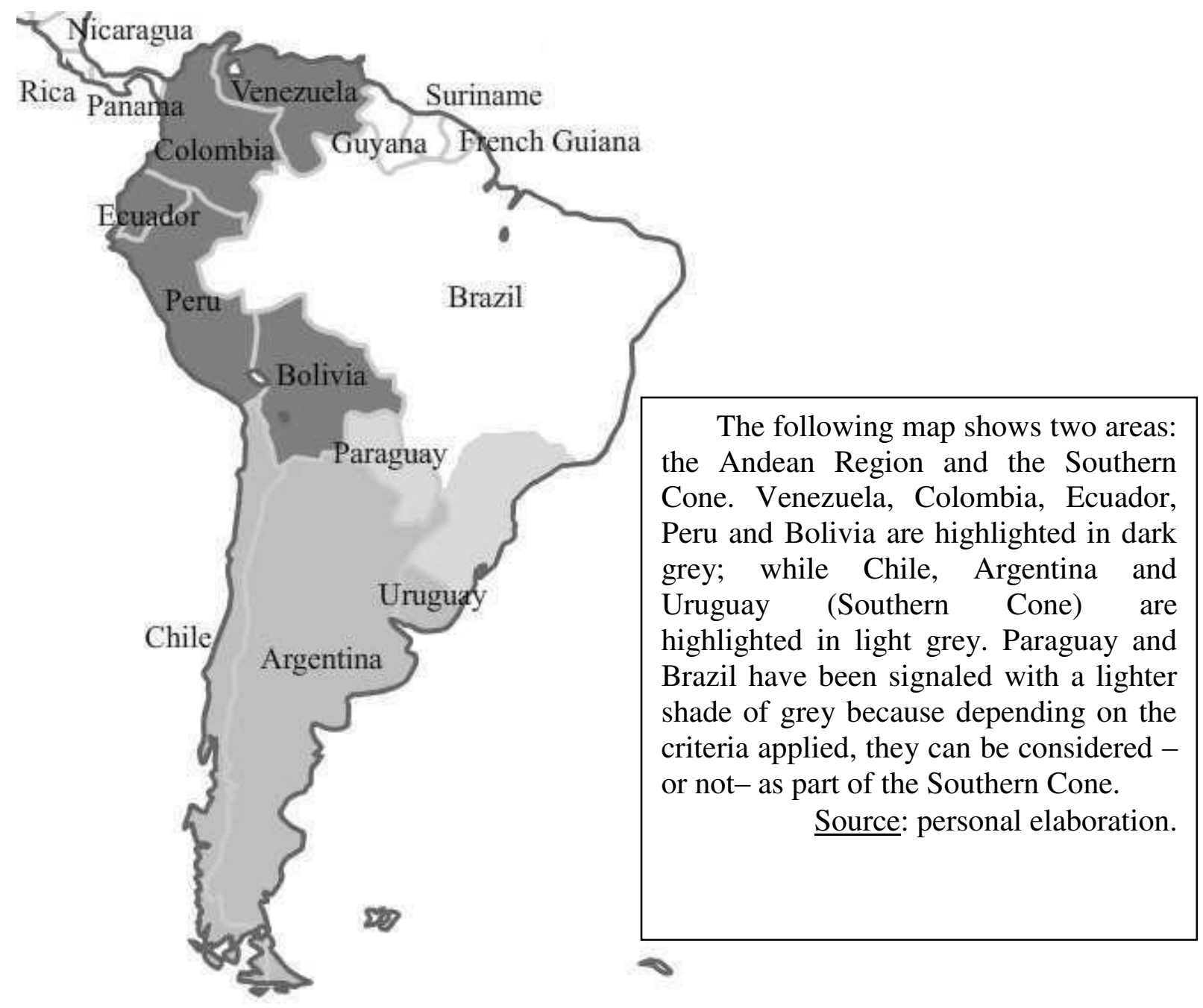


Figure 2: Regional and extra-regional actors involved in the continuum conflictcooperation within the coca-cocaine complete

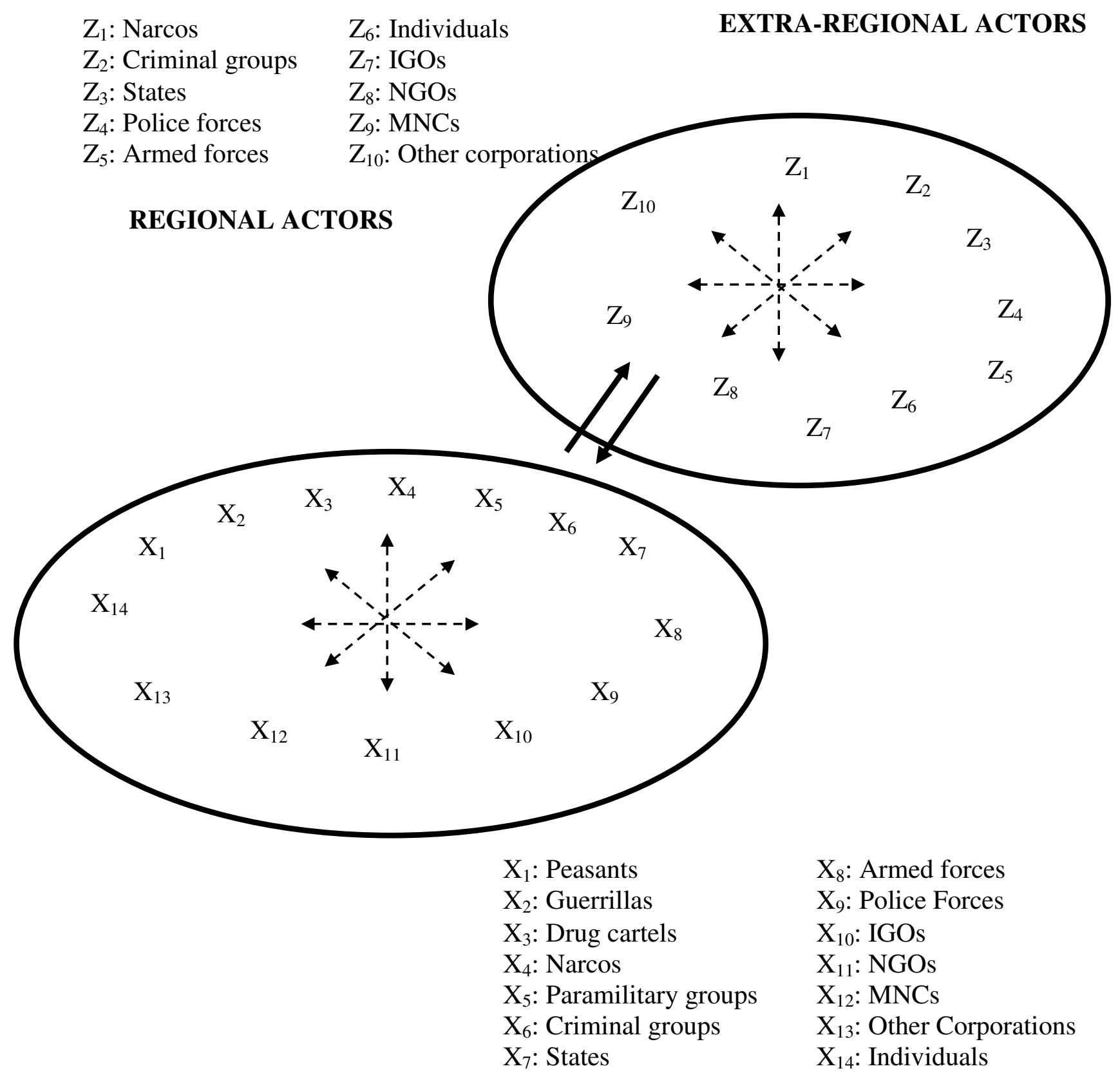

NOTE: This graphic, of personal elaboration, was inspired in that developed by Ivelaw L. Griffith to explain the conflict interactions in what he considers the Geonarcotics milieu (Griffith, 1997, 17). 


\section{References}

Belikow, Juan. Temas emergentes: terrorismo, narcotráfico, tráfico ilegal de personas, crimen organizado. Paper presented at the VI Encuentro Nacional de Estudios Estratégicos, Buenos Aires, Argentina, November 3-5, 2003.

Buzan, Barry. People, States \& Fear. An Agenda for International Security Studies in the post-Cold War Era. Colchester: ECPR Press, 2009.

Buzan, Barry., Wrever, Ole., and De Wilde, Jaap. Security: A New Framework for Analysis. Boulder (CO): Lynne Rienner, 1998.

Carrió, Elisa., Cinquierrui, Sebastián., and Martello, Walter. "Paco, la punta del iceberg", Afirmación para una República Igualitaria, September 2006. Accessed October 15, 2012. http://www.cinquerrui.com.ar/Archiv o/documentos/INFORME\%20PAC O.pdf

Dreyfus, Pablo. "Border Spillover: Drug Trafficking and National Security in South America." Ph.D. diss., Université de Genève, 2001. Accessed September 28, 2012. http://doc.rero.ch/record/2861/files LDreyfusP-these.pdf

European Monitoring Centre for Drugs and Drug Addiction (EMCDDA) and Europol, "Cocaine: A European Union perspective in the global context", April 2010. Accessed September 23, 2012. http://www.emcdda.europa.eu/html.c $\underline{\mathrm{fm} / \text { index101611EN.html }}$

Federico, Mauro. País narco. Tráfico de drogas en Argentina: del tránsito a la producción propia. Buenos Aires: Sudamericana, 2011.
Griffith, Ivelaw L. Drugs and Security in the Caribbean. Sovereignty Under Siege. Pennsylvania: Penn State Press, 1997.

International Crisis Group. "Latin American Drugs II: Improving Policy and Reducing Harm", Latin America Report $N^{\circ}$ 26, 14 March 2008. Accessed October 15, 2012. http://www.crisisgroup.org/ / media LFiles/latinamerica/ latin american drugs ii i mproving policy and reducing harm final.pdf

Lee, Rensselaer W. III. "Dimensions of the South American Cocaine Industry." Journal of Interamerican Studies and World Affairs 30 (1988): 87-103.

Lee, Rensselaer W. III. "Global Reach: The Threat of International Drug Trafficking", Current History 94 (1995): 207-211.

Mejía, Daniel., and Posada, Carlos E. "Cocaine production and trafficking: What Do We Know?" In Innocent Bystanders. Developing Countries and the War on Drugs, edited by Philip Keefer and Norman Loayza, 253-300. Basingstoke: Palgrave MacMilland \& The World Bank, 2010.

Siitonen, Lauri. "Political theories of development cooperation. A Study of Theories of International Cooperation", Institute of Development Studies, University of Helsinki, 1990. Accessed September 29, 2012. http://www.wider.unu.edu/publicatio ns/workingpapers/previous/en GB/wp-86/

Transnational Institute. "El paco bajo la lupa. El mercado de la pasta base de cocaína en el Cono Sur", Documentos de Debate Drogas y Conflicto $\mathrm{N}^{\circ} 14$, Buenos Aires, 2006. 
UNODC. "World Drug Report 2011", Division for Policy Analysis and Public Affairs. Accessed October 4, 2012.

http://www.unodc.org/documents/d ata-and-

analysis/WDR2011/World Drug Re

port 2011 ebook.pdf http://www.unodc.org/documents/d ata-andanalysis/WDR2012/WDR 2012 web small.pdf

Younger, Coletta and Rosin, Eileen. Drugs and Democracy in Latin America. Boulder (CO): Lynne Rienner, 2005.

UNODC. "World Drug Report 2012", Division for Policy Analysis and Public Affairs. Accessed October 4, 2012. 